IJ§ER

ISSN: $2149-5939$
International Journal of Social Sciences and Education Research

Online, http://dergipark.gov.tr/ijsser

Volume: 1(1), 2015

\title{
Peace activists in New Media
}

\author{
Mehmet Arslantepe ${ }^{1}$
}

Received Date: $01 / 01 / 2015$

Accepted Date: $01 / 02 / 2015$

\begin{abstract}
In this study, the way peace activists use new media and comments and reactions made for new activists in new media are analyzed. A review of transition from activism to digital activism and the impacts of this change was done with examples. WEB search method was used. First of all the concept of peace will be explained. I. Kant will be used in definition of peace culture. It will be stated that peace culture is experienced in different way in societies, and put forward what we understand of concept of peace and how we live peace. In line with peace culture, the concept of peace will be categorized and it will be determined mostly in which category activists are included. The universe of observing activists is composed of new media. Analysis of activists in this field will be done more efficiently due to rapid and versatile structure of new media. As a result, effectiveness, aim and interaction of peace activists in new media within defined peace culture will be determined.
\end{abstract}

Keywords: Peace, activizm, newmedia, Kant

\section{Introduction}

The definition of peace is mostly done by emphasizing the calmness that comes with the end of war / conflict. But peace does not occur by itself, it is a constituted case. (Ergil, 2010, p. 13). In order to explain the constructed situation, a culture of peace is required, which is slightly different than the definition of peace. All the definitions of peace in fact explain a cultural situation.

Culture of peace primarily comprises of democratic communication and tolerance. It does not inhabit violence. It requires dialogue. Culture of peace is actual. It requires vital areas such as education and art.

Culture of peace is a cognitive infrastructure (Ergil, 2010, p. 16). As it requires a cognitive effort, it might not be considered as attractive for the majority. Culture of violence, on the other hand, is about establishing supremacy, competition, basically action. Culture of peace does not include any structures that support and canonize violence. For instance, according to the dominant culture, concepts of being strong and gaining victory have been canonized in mythology, fairy tales, literature, cinema and so on. War and victory are the sides of culture that support violence. The works that require cognitive effort and the works for action are in fact the reflections of different cultures.

The concept of justice in our culture functions with punishment and this is the core of violence. We have to adopt the dominant structures. Our education system that requires us to prioritize on what all authorities think about us and it directed us to think within the context of award and punishment (Rosenberg, 2014, p. 26). Peace requires cultural values and ideologies compatible

\footnotetext{
${ }^{1}$ Assist. Prof. Dr., Kocaeli University, Faculty of Communication, KOCAELI/TURKEY, arslantepe@gmail.com 
Aslantepe, M. (2015). Peace activists in new media. International Journal of Social Sciences and Education Research, 1 (1), 207-211.

with peace. Artists and activists are required for a tendency to peaceful cultural values and ideology.

For instance, a myth was created that says a good life means punishing and ruling the bad people. And, this myth came through under the authoritarian regimes of leaders who call themselves king. Law systems were established on a punitive justice which supports the idea that award and punishment are deserved. (Rosenberg, 2014, p. 26, 114). Culture of war dominates the humanity and the world. Throughout the history, war has been an important subject for artists (Aytmatov, 2006, p. 25). And it was mostly canonized.

In order to make the culture of peace effective; social, political and economic justice needs to be provided first. In societies where structural injustice prevails, or in international relations; hatred, blood and fight are continuous. (Ergil, 2010, p. 19-20). Kant mentions the international peace based on human rights in his work Perpetual Peace. Kant has tried to ground peace in international relations. According to him, the duty of the philosopher is to think on peace. (Çörekçioğlu, 2012, p. 4).

According to Kant, war is a situation that can appear at any time. Therefore, perpetual peace is very important. An alliance of peace might end all the wars. An agreement of peace can only end a war. According to Kant, permanent armies must be abolished. Permanent armies are dangerous for other countries. And they also cause expenditures. According to him, another reason of wars are the countries that become rich. These countries also constitute a threat. (Kant, 1965, p. 9-11)

Kant defends a republican constitution. Because, according to him, a republican constitution stems from the principles of law. Ensuring the law is considered as necessary for peace. Even the laws need to have legal rules. Murdering innocent people or using poisonous weapons are illegal. In case such things happen, making peace with enemy cannot be realized; because the confidence is lost. (Kant, 1965, p. 18). Kant suggests federation for peace. According to him, uniting under a federation with the acceptance of all the states, will provide peace. (Kant, 1965, p. 22).

When we think as Kant does; we see that the injustice in international economy, weapons of mass destruction, migrations and terror make world peace impossible. (Mor, 2010, 534). But there are opinions against Kant, too. Zizek has proposed the impossibility of reaching perpetual peace. (Zizek, 2012, 181).

\section{Digital activism}

According to Kant, a philosopher must think on peace. Kant has thought to ensure the perpetual peace. He mentioned about peace on human rights, and he suggested that war can be resolved via international law. Peace requires a cognitive effort. People who are known as peace activists also try to establish a cognitive level. This concept can also be named as cultural activism and it has been on agenda since 1960s. Recently, it is more popular due to digital environment. It has relatively stepped out of the boundaries of being local or being silenced. Digital environment brings into mind that the work and federation/unification for the "international peace" that rests on human rights as mentioned by Kant has been approached. Kant has tried to ground peace in international relations. It can be argued that the cognitive efforts and implementations on this issue seem closer to be realized with the digital environment. 
Aslantepe, M. (2015). Peace activists in new media. International Journal of Social Sciences and Education Research, 1 (1), 207-211.

There are some contradictory views as well. Chomsky says: "The street activism that appeared at the end of $60 \mathrm{~s}$ was regressed but there is an atomized activism that still exists today. Various activist movements have appeared. Feminist movement, anti global warming movement, anti-war movement is only a few of those. These movements do not have any visible impacts. We cannot have the impact generated by the 60s activism today." (http://bianet.org/bianet/siyaset/125341chomsky-ozgurlukler-icin-surekli-mucadele).

Activism has increased in 1960s. Today, we observe that kind of activism among the Internet users. It is usually named as digital activism. Digital activism means to realize movements on various issues on the Internet. By using the ability of Internet to convey the information and news in a fast way, people can get organized on various issues.

Digital activism is classified as smart mobs and as flash mobs. Smart mobs are those acts realized for a specific purpose. Flash mobs define the activity organized by people coming together for fun. In both cases, the actions are common. (Silva and Frith, 2010, p. 485-490). It is seen that there are new forms of social organizations.

In such a case of activist utilization of Internet for organization, an action is done for a defended goal. This can be in the form of transmitting a message to the masses, collecting money or aid, or to reveal the truth. For instance, at one of the platforms where people can launch virtual campaigns, namely change.org; there were approximately 70 petitions per month in the first months of 2013; but in the first months of 2015 this number has reached to 200 per month. During 2014, 5,8 million people (7,5\% of the Turkish population) have participated to the petitions in these platforms. (http://www.dw.com/tr/sanal-aktivizm-gelişiyor/a-18302327)

As new communication technologies increase the amount of knowledge and provide access for individual communication with universal possibilities; they can be evaluated as a tool to realize participatory democracy (Karapinar, 2006: 97). Utilization of Internet and other new communication technologies narrow the gap between the rulers and the ruled. Thus, it helps to strengthen direct democracy. (Bektas, 2004: 211). When we look at the structural characteristic of the activists/participants of these new social movements; we see that they are high educated people with economic confidence and middle class university students (Offe,1999: 60).

Internet activists are operating at various different areas. When we look at known activists, we see that their areas of interest are to reveal the truth, libertarianism, providing justice and peace. These titles can in fact be the keywords of peace text's content of Kant's perpetual peace.

It is remarkable to see that the number of Internet activists is very high. But, as the research has started, it was seen that most of them did not have any function left after the activity. The number of those who continue their goals with consciousness are very rare when compared with those with temporary goals. We have selected the names with a certain goal, continuity and efficiency as Internet activists.

First name is Paul Craig Roberts, who is older than others and who was basically grown up as a reporter. It is seen that he criticizes Bush and Obama governments and stands against their war on terrorism and to policies on Israel. He writes his blog (paulcraigroberts.org) and uses YouTube for his videos. His blog has all the familiar characteristics. Blog consists of sections such as about, articles, interviews, books, guests and contact. Blog also has a donation button. He has stated that he quit working as a reporter for newspapers and that he will publish his articles via blog. Therefore, donations are needed. 
Gary Franchi is a libertarian activist and he publishes articles and reports. He aims to convey the real news. He has launched a network movement called Restore The Public (RTR). This movement is dedicated to the activist Aaron Russo who lost his life in 2007. Russo has revealed his opinion with movies and documentaries and he believed that America needed to be restored. Franchi's social network named RTR.org (Restore the Republic) has many members. Site suggests a revolution, an idea of restoring. Restore the Public consists of chapters such as news, blog, feed, members, groups and doc.

Another peace and freedom activist is Adam Kokesh and he was the center of many arguments due to his arrest video during the flash mob. He mentions a new American revolution where the federal government will be dispersed. He shares the concept at Adam vs The Man (adamvstheman.com) There are sections such as post cast, calendar, live, forum and contact. It is seen that he conveys his ideas via post casts more efficiently.

A Canadian blogger, Stefan Molyneux (molinyu) has intensified his works on anarchocapitalism, freedom and non-violence. Activist has a deep knowledge of history and philosophy. $\mathrm{He}$ is very efficient with his Post casts and YouTube videos. He is the founder of Freedomain Radio. According to anarcho-capitalism that he defends; the functioning of free market, social institutions, laws, security and infrastructure should not be arranged by the government but by profit seeking corporations, benevolent associations or by volunteers.

The issues covered by the four activists we mentioned here are the real news, reality, peace, freedom, re-organization and political-economic criticisms. As they use the new media and are very active on it, they can reach to a young audience. By looking at video comments and guest book articles, the profiles of followers can only be assumed.

\section{Conclusion}

Language of war is a language that contains actions and fear effects. In fact, it is a political discourse. It is mostly the language of politicians. They can increase their followers with a severe and strong language. It will not be easy to accept the language of peace in every field. People's awareness of culture of war and their follow-up of politicians and news with this awareness has great importance for the establishment of language of peace.

It is very hard for media to quit the discourse of war within the popular culture discourse. Language of war has become ordinary within the punitive cultural structure. First, the language of war should be aware. Throughout the history, there have been artists who do not use the language of war.

Artists and thinkers who express peace and culture of peace are needed in such an environment. With innovative and creative ideas, the cognitive situation necessary for culture of peace can be established today. With the increase of mobility, access to Internet is no longer a problem. But, new problems and research areas appear due to interruption on Internet access or utilization of Internet against peace.

As a result, the activists of freedom, democracy and peace exist today as the Internet activists. Democratic communication that is primarily necessary for culture of peace is created by new media. Digital activism is significantly important to make the culture of peace known by large masses. 
Aslantepe, M. (2015). Peace activists in new media. International Journal of Social Sciences and Education Research, 1 (1), 207-211.

\section{References}

Aytmatov, Cengiz (2006). Barış Kültürü Yılı, II. Kültür Kongresi Barış Kültürü, 16-18 Ekim 2000, İzmir. İstanbul: İKVS.

Bektaş, H., (2004). Bir Siyasal İletişim Aracı olarak Internet, s.211, Tablet Kitapevi, Konya.

Çörekçioğlu, H. (2012). “Kant ve Benjamin’de Şiddetin Tarihi Ve Hatırlama”, FLSF (Felsefe ve Sosyal Bilimler Dergisi), Bahar, sayı: 13.

Ergil, Doğu. (2010). Barışı Aramak. İstanbul: Timaş Yayınları.

I. Kant. (1965). Ebedi Barış Üzerine Felsefi Deneme. Ankara: Ankara Üniversitesi Siyasal Bilgiler Fakültesi Yayınları.

Gazalc1, Mustafa (2006). V. Oturum. II. Kültür Kongresi Barış Kültürü, 16-18 Ekim 2000, İzmir. İstanbul: İKVS.

Karapınar, K. (2006). Türkiye'de Sayısal Platform Yayıncılığı Ve Digitürk Beklentiler Ve Sorunlar', Yeni İletişim Ortamları ve Etkileşim Uluslararası Konferansı Kitabı Marmara Üniversitesi İletişim Fakültesi, İstanbul.

Mor, H. (2010). “Avrupa Birliği Bütünleşme Süreci Ve Sorunları”, Gazi Üniversitesi Hukuk Fakültesi Dergisi, C.14, S.1.

Offe, C. (1999), "Yeni Sosyal Hareketler: Kurumsal Politikanın Sınırlarının Zorlanması”, Yeni Sosyal Hareketler, (Editör: Kenan Çayır), Kaknüs Yayınları: İstanbul.

Rosenberg, Marshall B. (2014). Çatışma Ortamında Barış Dili (Can Baldan, Vivet Alevi, Çev). İstanbul: Maya Kitap.

Silva, A. D., ve Frith, J. (2010). Locative Mobile Social Networks: Mapping Communication and Location in Urban Spaces. Mobilities.

Zizek, S. (2012). “Kant İle Sade; İdeal Çift”, Cogito Dergisi, S. 41-42.

http://bianet.org/bianet/siyaset/125341-chomsky-ozgurlukler-icin-surekli-mucadele

http://www.dw.com/tr/sanal-aktivizm-gelişiyor/a-18302327 